\title{
INTERNATIONAL LAW AND THE ANGRY SUPERPOWER*
}

\section{Michael BYERS**}

RESUMEN: Una amplia empatía a raíz de los acontecimientos del 11 de septiembre, al igual que una gran preocupación por el terrorismo, ha hecho posible para Estados Unidos de América (EUA) el asegurar el tan buscado objetivo de una extensión del derecho a la legítima defensa, derecho bien establecido en la costumbre internacional, para incluir respuestas militares contra aquellos Estados que apoyan o dan refugio a grupos terroristas. Habiendo alcanzado ese objetivo, EUA puede ahora intentar desarrollar un derecho preventivo a la legítima defensa. Es posible también, indica el autor, que en vez de buscar un cambio en las reglas existentes, EUA esté intentando crear reglas nuevas o reglas de excepción para ellos únicamente. El autor nos advierte que el éxito en el cambio de reglas del derecho consuetudinario internacional al igual que del desarrollo de reglas de excepción, dependerá de las respuestas de otros países a tales acciones.

ABSTRACT: Widespread sympathy in the aftermath of 11 September and heightened concern about terrorism have made possible for the US the securing of a long-sought-after goal: an extension of the right of self-defence, a right well established in customary international law, to include military responses against States that support or harbour terrorist groups. Having reached that goal, the US may now try to develop a right of anticipatory self-defence. It is possible too, the author holds, that instead of seeking change in the existing rules, the US is in fact attempting to create new, exceptional rules for itself alone. The success in the changing of customary international rules as well as the development of exceptional rules, the author warns us, would depend on the responses of other countries to such actions.

RÉSUMÉ: La sympathie répandue au lendemain du 11 septembre et la grande préoccupation concernant le terrorisme ont rendu possible aux Etats-Unis d'assurer un but long temps cherché, une étendue du droit à la légitime défense, un droit très bien établi en droit international coutumier, à fin d'inclure les réponses militaires contre des Etats qui soutiennent ou abritent des groupes terroristes. En ayant atteint ce but, les Etats-Unis peuvent maintenant essayer de développer un droit à la légitime défense préventive. L'auteur maintient aussi, qu'il est possible que les Etats-Unis, au lieu de chercher à changer les règles existantes, essayent en faite de créer des règles exceptionnelles uniquement pour eux. L'auteur nous avertie que le succès pour changer les règles de droit international coutumier ainsi que pour le développement de règles exceptionnelles, dépendrait des réponses des autres pays à ces actions.

* Ponencia presentada en el seminario internacional "El derecho internacional".

** Associate Professor, Duke University School of Law; Peter North Visiting Fellow, Centre for Socio-Legal Studies \& Keble College, Oxford University. 
SUMARIO: I. Sleeping with the Elephant. II. American Unilateralism. III. Expanding the Right of Self-Defence. IV. The Making of Exceptional International Law. V. Standing up to Our Best Friend.

\section{SLEEPING WITH THE ELEPHANT}

In 1969, former Canadian prime minister Pierre Trudeau described Canada's relationship with the United States as like "sleeping with an elephant", comfortable and secure, but also dangerous should the gentle giant roll over in its sleep. ${ }^{1}$ But Canada is of course not alone in bed with the United States. The elephant also has a Latin lover - Mexico- a country with as much pride and potential as Canada, and just as acutely aware of the benefits and risks of sharing a continent with the world's most powerful state. As a Canadian, I come to Mexico with a strong awareness that, despite the distance between our two countries, we share a common dilemma: how to remain "best friends" with the United States while staying true to our own distinct identities, histories, and not least our desires for the futures of the countries we call our own.

The US Government wields more power than any regime since the Roman Empire. With 12 aircraft carriers, the only significant heavy airlift capacity and the only major stocks of precision guided missiles and bombs, it can defeat almost any opponent while suffering only minimal loses. And thanks to its massive defence budget, the US is the only country that regularly makes major advances in military technology. The determination to build a ballistic missile defence (BMD) system is but one example of a continued willingness on the part of the world's richest country to invest heavily in high-technology weapons so as to increase an already unassailable lead.

Decisions made on Wall Street and in Washington reverberate around the world. Corporate America, the regulatory infrastructure that supports it and the pension funds that propel it are the dominant influences on economic policy in Europe, Asia, Latin America and elsewhere, not to mention on the World Bank, the IMF and the WTO. The collapse of Enron may have demonstrated the fragility of corporate structures, but it also exposed the incestuous relationship between business and political elites.

1 Clarity, James, “Trudeau Pledges Independent Line”, New York Times, 26 de marzo de 1969, p. 15. 
Until its demise, Enron was more influential than all but a handful of nation states. Last year, I asked an Argentine diplomat what he thought about his country becoming part of the Free Trade Area of the Americas currently being negotiated at the initiative of a number of US-based corporations. He said, with evident regret, "We have no choice".

\section{AMERICAN UNILATERALISM}

A country as powerful as the US has many choices. Prior to the terrorist attacks of 11 September 2001, the new Bush Administration had set itself firmly on a unilateralist path. During the first eight months in office, it publicly rejected the Anti-Ballistic Missile Treaty, the Kyoto Protocol, the Rome Statute of the International Criminal Court (ICC), a convention on the sale and transfer of small arms and a protocol to the Biological Weapons Convention. ${ }^{2}$

Many thought that the initially measured response to the atrocities of 11 September heralded the beginning of a dramatically different, multilateral approach to foreign affairs. A "coalition" was constructed to facilitate the freezing of terrorist assets and the gathering of intelligence overseas. The support of numerous countries was sought and received for military action against the $\mathrm{Al}$ Qaeda terrorist network and the Taliban government of Afghanistan.

However, the United States'allies delude themselves if they think that the attacks on New York and Washington have persuaded the Bush administration of the more general value of multilateral approaches. Since 11 September, Bush and his advisers have rejected offers of a UN Security Council resolution authorising the war on terrorism, preferring instead to rely on an extended claim of self-defence. New alliances have been forged with illiberal regimes in Pakistan, Kyrgyzstan, Tajikistan and Uzbekistan, reversing years of carefully co-ordinated efforts to promote human rights. Hundreds of Afghan civilians have been killed or maimed as a result of careless targeting, and unexploded cluster bomblets will harm thousands more. The destruction of the al-Jazeera television bureau in Kabul, plans for special military commissions with low evidentiary standards and the refusal to accord detainees captured in Afghanistan presump-

2 The following Internet sites contain the texts of most international treaties: http://untreaty.un.org/; http://fletcher.tufts.edu/multilaterals.html. 
tive prisoner of war status - as required by the 1949 Geneva Convention - all indicate a casual disregard for international opinion and the laws of war.

Most disturbing, however, are some of the threats uttered by President Bush. The assertion that "you're either with us or against us" obviates a central aspect of state sovereignty — the right not to be involvedand recasts the US as the ultimate arbiter of right and wrong. The identification of an "axis of evil" comprising Iran, Iraq and North Korea challenges one of the twentieth century's greatest accomplishments: the prohibition of the threat or aggressive use of force in international affairs. In an age of ever-increasing interdependence, co-operation and shared values, Bush and his advisers are deliberately out of step with most of the Western world.

In many respects, Bush's team is a reincarnation of the second Reagan Administration, which was also stridently unilateralist; it, too, drew explicit distinctions between good and evil, claimed extended rights, promoted missile defence and relied on the threat of terrorism to justify it all. Following the terrorist bombing in 1986 of a Berlin discotheque frequented by American servicemen, the then Secretary of State George Shultz said that it was "absurd to argue that international law prohibits us from capturing terrorists in international waters or airspace; from attacking them on the soil of other nations, even for the purpose of rescuing hostages; or from using force against states that support, train and harbour terrorists or guerrillas". ${ }^{3}$

George W. Bush's speechwriter couldn't have put it better, though there are important differences between the situation then and now. First, the end of the Cold War transformed the US into an unrivalled superpower, making it more likely that such claims would meet with acquiescence on the part of other countries. More important, the events of 11 September have transformed a traditionally isolationist population into one that wants the President to act decisively on the world stage. And Bush's advisers have taken steps to ensure that Americans continue to feel this way, by connecting the "war on terrorism" to deeply held conceptions of nationhood. America is the shining "city on a hill", representing the best 
of the entrepreneurial, individualist spirit, and once again under assault from believers in a different God.

Powerful countries have always shaped the international system to their advantage. In the sixteenth century, Spain redefined basic concepts of justice and universality so as to justify the conquest of indigenous peoples in Mexico and elsewhere. In the eighteenth century, France developed the modern concept of borders, and that of the balance of power, to suit its continental strengths. In the nineteenth century, Britain introduced new rules on piracy, neutrality and colonialism - again, to suit its particular interests as the predominant power of the time- ${ }^{4}$

The present day US is no different, apart from the fact that, following 11 September, hardly anyone has been prepared to challenge its lead. The president's advisers are taking full advantage of the situation, applying pressure in pursuit of a wide range of goals that, in normal circumstances, might not be achieved. In January 2002, Bosnia handed over five Algerians to the US, despite the fact that the Bosnian Supreme Court had ordered them to be released due to lack of evidence: they are now in Guantanamo Bay. The UK is leading the stabilisation operation in Kabul and providing key support on both BMD and the issue of detainees. Russia has acquiesced in the establishment of American military bases in the former Soviet republics of Kyrgyzstan, Tajikistan and Uzbekistan. And China, having already witnessed the aggressive character of the Bush administration on two occasions - first on April 2001, after the crash-landing of a US surveillance plane, and then on its western border in Afghanis$\tan -$ is keeping quiet. The discovery of 27 listening devices in a Boeing 767 purchased for President Jiang Zemin has passed without complaint.

Canada, for its part, has been told to rescind its pledge to ratify the Kyoto Protocol, and to bring its immigration system into line with American procedures as part of the new emphasis on "homeland defence". It has already put hundreds of its soldiers under direct US command, and is considering doing the same with all of the rest within the context of the new, US-established "Northern Command" — which, incidentally, already extends geographically to include Mexico- ${ }^{5}$

4 On the geopolitical history of international law, see: Grewe, Wilhelm, The Epochs of International Law, Berlín, Walter de Gruyter, 2000.

5 In april of 2002, I wrote a report for Lloyd Axworthy, the former Minister of Foreign Affairs of Canada who now directs a centre for international studies at the University of British Columbia. The report, entitled "Canadian armed forces under US command", concludes with nine recommendations, the fourth of which is that Mexico should be included within any co-operative security arrange- 


\section{EXPANDING THE RIGHT OF SELF-DEFENCE}

Of the changes being pushed by the Bush administration, some of the most dramatic concern the international rules governing the use of force. Widespread sympathy in the aftermath of 11 September and heightened concern about terrorism have made possible the securing of a longsought-after goal: an extension of the right of self-defence to include military responses against states that support or harbour terrorist groups.

Article 51 of the UN Charter stipulates that acts of self-defence must be reported to the Security Council, but it does not define the content of that right. Self-defence is part of customary international law - an informal, unwritten body of rules derived from the practice and opinions of states-.${ }^{6}$ Necessity and proportionality are the key requirements. During the 1837 rebellion in Upper Canada (now the province of Ontario), British forces captured an American ship that was being used to supply the rebels on the Canadian side of the Niagara River, set it on fire and sent it over Niagara Falls. The US asserted that the UK had to show that this was a necessary and proportionate act of self-defence. The UK agreed with the American assessment of the legal requirements, and the modern law of self-defence was born. ${ }^{7}$

However, most claims of self-defence arise in circumstances that are confused and contested, with their contribution to the ongoing development of customary international law turning on whether they are widely accepted by other states. In 1976, Israeli commandos stormed a hijacked plane in Entebbe, Uganda, killing the pro-Palestinian hijackers and rescuing most of the passengers and crew. Although many of the passengers were Israeli, Israel itself had not been attacked. Nor had it sought Uganda's permission for the raid. But most states tacitly approved of what Israel had done and, as a result, the requirements of necessity and proportionality were loosened somewhat with regard to the rescue of nationals

ment. I quote from the report: "Mexico shares many of Canada's interests, concerns and vulnerabilities and could be a valuable ally within any North American security structure. Instead of both countries negotiating bilaterally with the US on security matters, it makes considerable sense, from a Canadian or Mexican perspective, for negotiations to occur trilaterally". For the report, see: http://www.liucentre.ubc.ca.

6 See generally: Akehurst, Michael, "Custom as a Source of International Law", 47 British Yearbook of International Law 1, 1974-1975.

7 See: Jennings, Robert, "The Caroline and McLeod Cases", 32 American Journal of International Law 82, 1938. 
abroad. ${ }^{8}$ In contrast, when Israel destroyed an Iraqi nuclear reactor in 1981, its claim of self-defence was firmly rejected by other states. ${ }^{9}$ A nuclear strike was not even imminent, and the requirements of necessity and proportionality were not fulfilled.

For decades, the US, Israel and apartheid South Africa argued that the right of self-defence extends to military responses to terrorist acts. But while the argument was accepted in a few specific instances, the pattern of response was never clear enough to establish new customary international law. Israel claimed to be acting in self-defence when it attacked the headquarters of the Palestine Liberation Organisation in Tunisia in 1985. The UN Security Council strongly condemned the action. ${ }^{10}$ The resolution was adopted with fourteen votes in favour and one abstention: the US. In 1998, after the bombings of its embassies in Kenya and Tanzania, the US fired cruise missiles at targets in Sudan and Afghanistan and claimed self-defence. A number of governments expressed concern about the fact that the territorial integrity of sovereign states was violated in an attempt to target not the states themselves but terrorists believed to be present there. ${ }^{11}$

Even when the country concerned is directly implicated in terrorism, acts of self-defence directed against it have - in most instances - received at best a mixed response. The US responded to the 1986 terrorist attack on the Berlin discotheque by bombing Tripoli, and claimed self-defence. The claim was widely rejected, with many states expressing doubt as to whether the attack on Libya was necessary and proportionate. ${ }^{12}$ In 1993, in Kuwait, an assassination attempt was made on George Bush Snr. The US responded by bombing the headquarters of the Iraqi Secret Service. It claimed self-defence on the basis that the attack on the ex-president was tantamount to an attack on the US itself. Again, the claim received little support from other states. ${ }^{13}$

8 See: Akehurst, Michael, "The Use of Force to Protect Nationals Abroad", 5 International Relations 3, 1977.

9 See: Security Council Res. 487 (1981) (unanimous), http://www.un.org/documents/scres.htm

10 Security Council Res. 573 (1985), http://www.un.org/documents.scres.htm.

11 See, e. g.: Final Document of the XIIth Summit of the Non-aligned Movement, 2 y 3 de septiembre de 1998, Durban, South Africa, http://www.nam.gov.za/xiisummit/, para. 159.

12 See: Gray, Christine, International Law and the Use of Force, Oxford, Oxford University Press, 2000, pp. 116 y 117.

13 See: Kritsiotis, Dino, "The Legality of the 1993 US Missile Strike on Iraq and the Right of Self-Defence in International Law”, 45 International \& Comparative Law Quarterly 162, 1996. 
In the Nicaragua Case, the International Court of Justice accepted that self-defence could include responses to the "sending by or on behalf of a State of armed bands, groups, irregulars or mercenaries, which carry out acts of armed forces against another State of such gravity as to amount to (inter alia) an actual armed attack conducted by regular armed forces, or its substantial involvement therein". ${ }^{14}$ In other words, the Court held that an "armed attack" exists only when the link between the state and the non-state actor is very close, and the attack is of a seriousness akin to an attack by a state. This position is consistent with the law of state responsibility insofar as it concerns the attribution of the acts of non-state actors to a state. ${ }^{15}$

In late September 2001, the US found itself in something of a legal dilemma, though not an entirely unhelpful one. In order to maintain the coalition against terrorism, its military response had to be necessary and proportionate. This meant that the strikes had to be carefully targeted against those believed responsible for the atrocities in New York and Washington. But if the US singled out Osama bin Laden and al-Qaeda as its targets, it would have run up against the widely held view that terrorist attacks, in and of themselves, did not justify military responses against sovereign states. Even today, most countries would not support a rule that opened them up to attack whenever terrorists were thought to operate within their territory.

In response to this dilemma, the US adopted a two-pronged legal strategy. It began by expanding its focus to include the Taliban. By giving refuge to bin Laden and al-Qaeda and refusing to hand him over, the Taliban were alleged to have directly facilitated and endorsed his acts. The US in this way broadened the claim of self-defence to include the

14 (1986) ICJ Reports 14 at 103, para. 195.

15 Under the customary international law of state responsibility, states are only responsible for those acts of private individuals or groups over which they exercise "effective control". See: Art. 8, ILC Draft Articles on State Responsibility, in "Report of the International Law Commission on the work of its Fifty-third session", Official Records of the General Assembly, Fifty-sixth session, Supplement No. 10 (A/56/10, chp.IV.E.2), available at http://www.un.org/law/ilc/index.htm ("The conduct of a person or group of persons shall be considered an act of a State under international law if the person or group of persons is in fact acting on the instructions of, or under the direction or control of, that State in carrying out that conduct"); Commentary to Article 8, ibidem, p. 104, para. 3 ("Such conduct will be attributable to the State only if it directed or controlled the specific operation and the conduct complained of was an integral part of that operation"). 
state of Afghanistan. Although it would normally still be contentious, this was much less of a stretch from pre-existing international law than a claimed right to attack terrorists who simply happened to be there. As a result, the claim to be acting in self-defence - and the modification of customary international law inherent within that claim - had a much better chance of securing widespread expressed or tacit support.

The US then worked hard to secure that support in advance of military action. The formation of the coalition, including the invocation of Article 5 of the 1949 North Atlantic Treaty and Article 3(1) of the 1947 Inter-American Treaty of Reciprocal Assistance, even though neither NATO nor the parties to the Inter-American Treaty were called upon to engage in military action, helped smooth the path for the self-defence claim. UN Security Council resolutions adopted on 12 and 28 September 2001 did not authorise the use of force under the UN Charter, but instead were carefully worded to affirm, within the context of a broader response to terrorism, the right of self-defence in customary international law. ${ }^{16}$

The strategic effort to secure advance support built upon an approach previously used in 1998. A few short hours before he ordered the cruise missile strikes against terrorist targets in Sudan and Afghanistan, Bill Clinton telephoned Tony Blair, Helmut Kohl and Jacques Chirac and requested their support. Without having time to consult their lawyers, all three leaders agreed - and followed this up with public statements immediately after the strikes-. ${ }^{17}$ Criticism of the military action by other states was, consequently, more restrained that it might have been. And this relatively restrained response facilitated the eventual modification of customary international law that has now occurred: states now have the right to engage in self-defence against states which actively support or willingly harbour terrorist groups who have already attacked the responding state.

Personally, I do not support this change; I am here simply describing the result of my analysis as an academic international lawyer. But my lack of support concerns the fact that this change may be of considerable significance in future. Having seized the opportunity to establish self-defence as an accepted basis for military action against some terrorist acts, the US will now be able to invoke it again - even when the circumstances are less grave-.

16 See: Security Council Res. 1368 \& 1373, http://www.un.org/documents/scres.htm.

17 Drozdiak, William, "European Allies Back US Strikes; Japan Says It 'Understands'”, Washington Post, 21 de agosto de 1998, A20. 
The US may now be employing similar strategies to develop a right of anticipatory self-defence. Until 11 September, claims of a right to preemptive action were invariably contested. In fact, Article 51 of the UN Charter states that the right of self-defence arises when "an armed attack occurs" and most countries have, since 1945, been very reluctant to claim a right of anticipatory self-defence. Israel justified the strikes that initiated the 1967 Six Day War on the basis that Egypt's blocking of the Straits of Tiran was a prior act of aggression. The US justified its 1962 blockade of Cuba on the basis of Chapter VIII of the UN Charter, as regional peacekeeping, and the 1988 downing of an Iranian civilian Airbus as a response to an ongoing armed attack. There is almost no support for a right of anticipatory self-defence, as such, in present day customary international law. ${ }^{18}$

This does not mean that this aspect of the law will remain unchanged. In a letter to the president of the Security Council on 7 October 2001, US Ambassador John Negroponte wrote: "We may find that our self-defense requires further actions with respect to other organizations and other states". ${ }^{19}$ When this sentence is read together with subsequent statements indicating a willingness to act against countries such as Iran, Iraq and North Korea, on the basis that they are developing weapons of mass destruction threatening to the US, it becomes clear that the Bush administration is contemplating widespread military action that it would justify as anticipatory self-defence. Whether this action, and the attempt at its legal justification, extend the right of self-defence yet further will depend on how other countries respond. If they do not protest against the US action, if and when it comes, their behaviour could well constitute acquiescence in yet another change to customary international law.

\section{THE MAKING OF EXCEPTIONAL INTERNATIONAL LAW}

The Bush administration also seems to be engaged in a parallel effort to remake - in favour of the US - the rules according to which interna-

18 For a more detailed analysis see: Gray, Christine, International Law and the Use of Force, Oxford, Oxford University Press, 2000, pp. 111-115.

19 UN Doc. S/2001/946, available at http://www.un.int/usa/s-2001-946.htm. See also: Wren, Christopher, "US Advises UN Council More Strikes Could Come", New York Times, 9 de octubre de 2001, B5. 
tional law is made, interpreted and changed. It increasingly adopts an approach to treaty interpretation that focuses on the supposed purposes of the treaty rather than what the words actually say. It accords considerably more weight to physical acts than to statements when weighing state behaviour with regard to customary international law, and discounts entirely the resolutions and declarations of the UN General Assembly. It pays little if any attention to decisions of the International Court of Justice - even though most other countries regard them as authoritative pronouncements on the existence and content of specific rules of international law-. As a result, international law as applied by the US increasingly bears little relationship to international law as understood elsewhere. It remains to be seen whether, and to what degree, this divergence will influence the approach taken by other countries. ${ }^{20}$

It is possible, however, that instead of seeking change in the existing rules, the US is in fact attempting to create new, exceptional rules for itself alone. Similar exceptional rules have been created by other countries in the past, albeit on a more limited basis. In 1984, West Germany abandoned its universally accepted claim to a three-mile territorial sea in the waters off Hamburg and claimed a new, unprecedented limit on the basis of a 16-mile box defined by geographical co-ordinates. The new claim, which was explicitly designed for the limited purpose of preventing oil spills in those busy waters, met with no public protests from other states. This was perhaps because the balance of interests in that situation was different from that which existed more generally — different enough that other countries were prepared to allow for the development of an exception to the general rule-. ${ }^{21}$

The same might be said of the position and interests of the single superpower in the post-Cold War period, in which case the development of exceptional rules would depend on the responses of other countries to the exceptional claims. And given the potentially substantial political, military and economic costs of opposing the US in any particular law-making situation, acquiescence might well occur - at least with regard to those claims that are not substantially contrary to the most important interests

20 For a more detailed analysis see: Byers, Michael, "The Shifting Foundations of International Law: A Decade of Forceful Measures against Iraq", 13 European Journal of International Law 21, 2002.

21 See: Byers, Michael, Custom, Power and the Power of Rules, Cambridge, Cambridge University Press, 1999, p. 95. 
of others- - In short, although international law is what countries choose it to be, the power dynamic behind the law might in fact leave the less powerful believing that they have little choice but to allow the creation of precisely such an exceptional legal regime.

What would such a regime look like? The Bush Administration would clearly wish it to have an imperial tinge, with the US serving as global law-maker and sheriff, setting the rules and acting alone or at the head of a posse of compliant allies to impose discipline and stamp out foreign threats. The security regime established by the UN Charter in 1945, whereby the five permanent members of the Security Council - China, France, Russia, the UK and the US - were collectively given executive powers to maintain international peace and security, imposes potentially inconvenient limits on the discretionary powers of a newly confident hegemon and must, therefore, be firmly pushed aside.

Efforts at the creation of an exceptional regime are also being made elsewhere. The Anti-Ballistic Missile Treaty and Geneva Convention have both been described as "outdated", implying that the US is not bound by treaties entered into before the end of the Cold War. International human rights are similarly regarded as no longer binding on the US: in addition to the new links with illiberal regimes, the Bush administration has dismissed reports of abusive treatment of detainees in Afghanistan and Guantanamo Bay on the basis that the treatment is consistent with US standards. However, we can expect international human rights to remain part of the diplomatic arsenal of the State Department when it comes to the behaviour of other countries, such as China, Iran, Iraq and North Korea.

The greatest threat to the long-term survival of the human species may well be climate change rather than terrorism. But the Bush administration, heavily funded by the oil industry and inherently suspicious of "entangling alliances", has rejected the developing international regulatory system on the emission of greenhouse gases. It has taken a similar stance towards the ICC. ${ }^{22}$ When the ICC comes into being in 2003, it will face the active opposition of a single superpower angry that the actions of its soldiers - and thus its military policy — might be held up to scrutiny 
by foreign judges. Others may wish to promote an illusionary common good through the Kyoto Protocol and the ICC, but the US acts alone.

\section{STANDING UP TO OUR BEST FRIEND}

Terrorism can cause great destruction and upheaval, but efforts to stamp it out can also be a smokescreen for the pursuit of other, less worthy goals. Friends and allies of the US, while providing strong overall support, should offer their co-operation on specific issues only after thinking carefully about what is best for themselves. Recent statements by European Union Commissioner Chris Patten, German Foreign Minister Joschka Fischer and former French Prime Minister Lionel Jospin show that some prominent Europeans are at last voicing concern about American unilateralism in the post-11 September world. These voices should not be dismissed as anti-American. Respect for diversity of opinion is, after all, a central aspect of American society, and differing points of view are never far away. Most Americans currently support the president, but less that half of them voted for him. The Democratic Party has been revitalised by the Enron scandal and reports that Bush was warned in advance of the 11 September attacks. Even within the administration there are public differences over such issues as the treatment of detainees, and the involvement of the US in peace efforts in Israel and Palestine.

The views expressed by Patten, Fischer and Jospin reflect deep-seated concerns on the part of some of the United States' best friends that the Bush administration is taking the country away from its most valuable and deep-seated traditions. One regularly hears talk of a "democratic deficit" with regard to supra-national institutions such as the UN and EU, but perhaps it is time to start speaking of a similar deficit with regard to the US. The importance of decisions made in Washington today eclipses that of decisions made in the UN — and not just for Americans-. Citizens of other countries find themselves in a position of considerable historical irony: the victims of a twenty-first-century form of "taxation without representation", subject to the governance of a foreign power but deprived of any voice.

Maintaining the integrity and equal application of the international legal system is the most effective way in which we can begin to address this problem. Although imperfect, the international rules and institutions rejected by Bush and his advisers are more consistent with the founding 
principles of the US than the imperialist principles to which they subscribe. Even the Declaration of Independence recognised that the representatives of the US were required to have a "due regard for the opinions of other nations". It is high time that more of the United States' friends made themselves heard, and insisted that the immense power of the US be channelled through existing international rules and institutions, and thus used to improve the world - for everyone-. Canada and Mexico, already in bed with the elephant, should lead the way. 